UDC 614.71

DOI: $10.21668 /$ health.risk/2020.4.04.eng

Research article

\title{
ON IMPLEMENTATION OF «CLEAN AIR» FEDERAL PROJECT IN OMSK
}

\section{A.S. Kriga ${ }^{1}$, S.V. Nikitin ${ }^{2}$, E.L. Ovchinnikova ${ }^{2,3}$, O.V. Plotnikova ${ }^{3}$, A.S. Kolchin ${ }^{3}$, M.N. Cherkashina ${ }^{2}$, I.G. Vinokurova ${ }^{2}$, M.A. Dunaeva ${ }^{2}$}

${ }^{1}$ Federal Service for Surveillance over Consumer Rights Protection and Human Wellbeing, Omsk Region office, 9810 let Oktyabrya Str., Omsk, 644001, Russian Federation

${ }^{2}$ Center for Hygiene and Epidemiology in Omsk region, 42 A 27-ya Severnaya Str., Omsk, 644116, Russian Federation

${ }^{3}$ Omsk State Medical University, 12 Lenina Str., Omsk, 644099, Russian Federation

The first two years of «Clean air» Federal project in Omsk have been completed and preliminary results have been estimated.

The present work deals with issues related to implementation of the Complex program aimed at reducing emissions, highlights the sanitary-epidemiologic situation related to air contamination in settlements, and describes activities aimed at optimizing a laboratory network used for monitoring over ambient air quality. It is essential to obtain maximum objective data on population health risks caused by ambient air contamination at the initial stage of the Federal project implementation.

Our research goal was to estimate intermediate results in the Federal project implementation taking into account preliminary analysis of sanitary epidemiologic welfare in Omsk related to ambient air contamination.

Our research object was ambient air quality in Omsk, potential health risks and population health parameters associated with ambient air contamination over 2009-2019.

The examination was performed in accordance with a procedure for health risk assessment under exposure to chemicals (R 2.1.10.1920-04), as well as procedures, approaches, and algorithms stipulated in the normative and methodological documents MR 2.1.6.0158-19, MR 2.1.6.0156-19, with use of geoinformation technologies and statistical procedures.

The research allowed substantiating a program for monitoring over ambient air quality taking into account all the existing monitoring systems basing on spatial distribution of total hazard quotient (S) in Omsk residential area and preliminary data obtained via aggregated calculations of ground contaminants concentrations. We suggested a list of control parameters and a procedure for their estimation in order to provide objective and timely monitoring over implementation of the Complex program aimed at reducing emissions into ambient air in Omsk. Implementation of the Complex program was estimated as per results of certain activities accomplished within it in 2019.

Key words: «Clean air» Federal project, ambient air contamination, emissions, priority contaminants, monitoring, health risk, population health.

(C) Kriga A.S., Nikitin S.V., Ovchinnikova E.L., Plotnikova O.V., Kolchin A.S., Cherkashina M.N., Vinokurova I.G., Dunaeva M.A., 2020

Aleksandr S. Kriga - Candidate of Medical Sciences, Supervisor (e-mail: rpn@55.rospotrebnadzor.ru; tel.: +7 (3812) 32-60-32; ORCID: https://orcid.org/0000-0002-2597-6662).

Sergei V. Nikitin - Candidate of Medical Sciences, Chief Physician (e-mail: fbuz55@mail.omsksanepid.ru; tel.: +7 (3812) 68-09-77; ORCID: https://orcid.org/0000-0002-8629-2264).

Elena L. Ovchinnikova - Candidate of Medical Sciences, Physician, Associate professor (e-mail: fbuz55@mail.omsksanepid.ru; tel.: +7 (3812) 68-09-77, +7 (913) 649-10-90; ORCID: https://orcid.org/0000-0002-9970-7617).

Ol'ga V. Plotnikova - Candidate of Medical Sciences, Associate professor, Head of the Department (e-mail: olga.plotnikova7@mail.ru; tel.: +7 (913) 974 31-36; ORCID: http://orcid.org/0000-0002-0696-3516).

Andrei S. Kolchin - Candidate of Medical Sciences, Associate professor (e-mail: kandsmed@yandex.ru; tel.: +7 (913) 679-90-11; ORCID: https://orcid.org/0000-0001-5149-1784).

Marina N. Cherkashina - Head of the Department for Activities Organization and Provision (e-mail: fbuz55@mail.omsksanepid.ru; tel.:+7 (3812)68-09-77; ORCID: https://orcid.org/0000-0002-9649-8784).

Irina G. Vinokurova - Head of the Department for Social and Hygienic Monitoring (e-mail: fbuz55@mail.omsksanepid.ru; tel.: +7 (3812) 68-09-77; ORCID: https://orcid.org/0000-0002-9712-9673).

Marina A. Dunaeva - Head of the Department for IT and Software Provision (e-mail: fbuz55@mail.omsksanepid.ru; tel.: +7 (3812) 68-09-77; ORCID: https://orcid.org/0000-0001-9961-4480). 
«Clean air» Federal project, just like every national project, was started in 2017 when first activities within it were implemented. In accordance with the goals set within the Federal project a primary task in monitoring is to accomplish control over reduction in aggregated volumes of contaminants emissions that should decrease by not less than $20 \%$ by 2024 ; another task is growth in a share of citizens living in large industrial centers who are satisfied with ambient air quality and this share should reach $90 \%$.

The Federal Service for Surveillance over Consumer Rights Protection and Human Wellbeing is an active participant in the Federal project responsible for its implementation; due to its declared mission and activity goals the Service can't limit its contribution only to reduction in emissions; its tasks are wider and include improvement in population health associated with ambient air quality ${ }^{1}$. A reduction in aggregated emissions by a preset value does not necessarily result in favorable ambient air quality in case health risks are not taken into account; consequently, it can't lead to a substantial improvement in population life quality $[1,2]$.

The project implementation should take place over quite a long period time, namely 5 years; in spite of that population health as an ultimate result of such activities has long-term inertia. Not long ago, on July 21 2020, the RF President issued an Order No. 474 on national goals in the state development; the Order fixed new control «indicators» that should be reached by 2030 and among them there is «a 2-time reduction in emissions of hazardous contaminants that exert the most negative influence on the environment and human health ${ }^{2}$. New goals should substantially intensify activities aimed at reducing emissions, first of all, when it comes to priority contaminants. And it is advisable to include exactly those technical and organizational activities into Complex programs aimed at emissions reduction within the Federal project that will allow required wide-scale reduction in emissions of priority contaminants in future. In accordance with the Federal Law issued on July 26, 2019 No. 195-FZ on accomplishing an experiment on fixing quotas for emissions, priority contaminants are those substances which, when emitted, not only result in violated hygienic standards but also create health risks ${ }^{3}$. Therefore it is vital to choose relevant activities exactly at early stages in project implementation that will make for a substantial decrease in medical and demographic losses.

Our research goal was to assess preliminary results (2018-2019) achieved in the Federal project implementation taking into account preliminary analysis of sanitary-epidemiologic welfare of the population living in Omsk associated with ambient air contamination.

Data and methods. We assessed ambient air quality in Omsk, potential health risks and health indicators associated in ambient air contamination in residential areas over 2018-2019. To do that, we took data from official statistic data sources provided by federal and regional executive authorities (Rosprirodnadzor, Rospotrebnadzor, the Federal Statistics Service, the RF Public Healthcare Ministry, the RF Ministry of Natural Resources and the Environment).

Population health risks were assessed according to health risk assessment methodology applied in case of exposure to chemicals (Guide R 2.1.10.1920-04) ${ }^{4}$. We applied methodical approaches, procedures, and algorithms suggested by Rospotrebnadzor's scientific research organizations to analyze a sanitary-

\footnotetext{
${ }^{1}$ On sanitary-epidemiologic welfare of the population in the Russian Federation in 2019: The State Report. Moscow, The Federal Service for Surveillance over Consumer Rights Protection and Human Well-being Publ., 2020, 299 p. (in Russian).

${ }^{2}$ On national goals in the RF development for a period up to 2030: The RF President Order issued on July 21, 2020 No. 474. KonsultantPlus. Available at: http://www.consultant.ru/document/cons_doc_LAW_357927/(30.07.2020) (in Russian).

${ }^{3}$ On accomplishing an experiment on fixing quotas for emissions of contaminants and making alterations into certain RF legislative acts as regards reduction in ambient air contamination: The Federal Law issued on July 26, 2019 No. 195-FZ. KonsultantPlus. Available at: http://www.consultant.ru/document/cons_doc_LAW_329955/(30.07.2020) (in Russian).

${ }^{4}$ Guide R 2.1.10.1920-04 The Guide on assessing health risks under exposure to chemicals that pollute the environment. KODEKS: an electronic fund for legal and reference documentation. Available at: http://docs.cntd.ru/document/1200037399 (30.07.2020) (in Russian).
} 
epidemiologic situation that characterized ambient air quality and its influence on population health, substantiation of activities aimed at reducing emissions, and creation of an updated interdepartmental monitoring and laboratory network. The approaches and procedures included those developed as methodical support for «Clean air» Federal project (Methodical Guidelines MR 2.1.6.0156-19 «Assessment of ambient air quality and health risk analysis aimed at making well-grounded managerial decisions in providing proper ambient air quality and sanitary-epidemiologic welfare of the population»; MR 2.1.6.0157-19 «Creation of programs for monitoring over ambient air quality and quantitative assessment of population exposure for fulfilling tasks within social-hygienic monitoring activities»).

We applied geoinformation technologies and statistic procedures in our research.

Results and discussion. By 2017, a year when the first activities were implemented within the Federal project, Omsk occupied the $9^{\text {th }}$ rank place among cities and municipal districts in the Russian Federation where «contaminants emissions into ambient air from stationary sources» ${ }^{5}$ were the highest.

Developed petrochemical industry with its growing production outputs, coal-powered heat-generating industries, motor transport, and autonomous heat supply units created aggregated ambient air contamination in the city that was higher than hygienic standards (maximum single concentrations) as per aromatic hydrocarbons (primarily xylene, toluene, and phenol), formaldehyde, benzpyrene, particulate matter, sulfur dioxide, nitrogen oxides, and carbon oxide. Up to 2017, practically every year formaldehyde and hydrogen chloride were registered in concentrations that were up to more than 10 times higher than single maximum MPC.
Ambient air in Omsk contains certain contaminants in concentrations that are higher than reference ones and create long-term chronic inhalation exposure; it is true for formaldehyde (concentration is 2.3 times higher than the reference level); copper (2.5 times higher); and manganese (1.4 times higher). In 2017 concentrations of $\mathrm{PM}_{2.5}$ were 1.3 times higher than its maximum permissible average annual and average daily ones; $\mathrm{PM}_{10}, 1.4$ times; formaldehyde, 1.07 times; benzpyrene, 1.9 times.

Over the whole observation period potential and actual population health in the city associated with ambient air quality was characterized with elevated carcinogenic and noncarcinogenic health risks, elevated overall mortality and morbidity, as well as unfavorable dynamics being especially negative in years prior to 2015 .

Over the last 10 years individual carcinogenic risk was higher than its permissible level; according to risk levels classification ${ }^{6}$ this risk was estimated as «alerting» and in 2017 it amounted to $2.45 \cdot 10^{-4}$.

Priority risk-creating carcinogens include formaldehyde, benzene, carbon black, benzpyrene, and some metals such as chromium, nickel, cadmium, and lead.

Population health risks in Omsk caused by non-carcinogenic effects produced by contaminants were also higher than their permissible levels over a long-term observation period; by 2017 non-carcinogenic hazard index for the respiratory organs amounted to 9.8 (high risk).

Risks related to non-carcinogenic negative effects produced on the respiratory organs to the greatest extent depend on aggregated volumes of contaminants emissions into ambient air. Their value is influenced by average daily (average annual) concentrations of most contaminants including formaldehyde (average long-term hazard quotient is equal to 2.7), par-

\footnotetext{
${ }^{5}$ On the ecological situation and environmental protection in the Russian Federation in 2018: The State Report. Moscow, the RF Ministry of National Resources and the Environment; NPP «Kadastr» Publ., 2019, 844 p. (in Russian).

${ }^{6}$ Risk levels here and so on estimated in accordance with a classification suggested in the Methodical Guidelines MR 2.1.6.0156-19. «Assessment of ambient air quality and health risk analysis aimed at making well-grounded managerial decisions in providing proper ambient air quality and sanitary-epidemiologic welfare of the population»: methodical guidelines. Moscow, 2019 (in Russian).
} 
ticulate matter, soot, hydrogen chloride, metals (copper, manganese, chromium, cadmium, nickel, and lead), nitrogen oxide, nitrogen dioxide, carbon oxide, ammonia, and some others.

Data taken from multiple scientific research works confirm that the said contaminants exert their influence on development of respiratory diseases that have different gravity [3-8].

Average annual hazard indexes that show possibility of non-carcinogenic systemic effects produced on a body as well as on the immune system were long within «alerting risk level» range and went down to «acceptable risks» only by 2017 .

It was established that health risks were unacceptable in all 12 cities where the Federal project activities were implemented; predominantly, those risks were related to negative effects produced on the respiratory organs, blood system, development, immune system, cardiovascular system, central nervous system (CNS), and reproductive system ${ }^{7}$.

Calculated health risks correlate well with data on actual population health. As per data provided by scientific research on territories where petrochemical industry is well developed overall morbidity among children tends to be 1.7 times higher than on average in the country; and as for its structure, respiratory pathologies among children tend to be 1.4 times higher; gastrointestinal tract diseases, 1.2 times higher; skin and subcutaneous tissue diseases, 1.7 times higher [9].

Having comparatively analyzed average long-term health indicators in Omsk region, the Russian Federation, and the Siberian Federal District (SFD), we determined priority ones that were authentically higher in Omsk region than on average in the country and, which is especially important, higher than average health indicators in the SFD as in this case there are the most similar climatic and socioeconomic conditions.

Thus, in 2017 priority health indicators included mortality caused by all reasons (1,292.0 deaths per 100 thousand people) in- cluding deaths caused by respiratory diseases (57.7 deaths per 100 thousand people), malignant neoplasms (490.6 deaths per 100 thousand people), infant mortality (6.9 deaths per 1,000 infants who were born alive), and perinatal mortality ( 8.01 per 1,000 infants born both dead and alive), as well as mortality among employable population.

According to the WHO documents there is conclusive evidence proving a correlation between ambient air contamination and infant mortality. Besides, when infant children are exposed to ambient air contamination, it is highly likely to result in unfavorable outcomes as they grow and in their adult life as well [3].

In 2009-2015 overall primary morbidity among population in Omsk was higher than on average in the country and in the Siberian Federal District and tended to grow; the first decrease in morbidity was detected after 2015 . In 2017 priority diseases included diseases of the blood and blood-forming organs and certain disorders involving the immune mechanism (5.8 cases per 100 thousand people); diseases of the circulatory system (43.3); diseases of the digestive system (90.7); diseases of the skin and subcutaneous tissue (42.5): endocrine, nutritional, and metabolic diseases (26.7): and congenital malformations (2.6). Regional morbidity was the most apparently higher than on average in the country for endocrine diseases $(90.7 \%)$; diseases of the circulatory system $(34.9 \%)$; congenital malformations $(30.0 \%)$, and diseases of the digestive system $(166.8 \%)$.

In our opinion, these figures are not accidental at all as the gastrointestinal tract, skin, and respiratory organs are natural barriers that should prevent chemicals from entering the internal environment of a human body. Living in a zone where anthropogenic loads on the environment are high is proven to result in $78 \%$ growth in risks of gastroenterological pathology [9].

We should note that respiratory diseases were not listed among priority ones during the

\footnotetext{
${ }^{7}$ On sanitary-epidemiologic welfare of the population in the Russian Federation in 2019: The State Report. Moscow, The Federal Service for Surveillance over Consumer Rights Protection and Human Well-being, 2020, 299 p. (in Russian).
} 
whole observation period (as opposed to mortality caused by them) but morbidity with respiratory diseases among adults grew steadily up to 2017 including morbidity with chronic bronchitis. There was also a gradual increase in morbidity with asthma in all age groups, and in 2017 morbidity with asthma and status asthmaticus among adults and teenagers turned out to be the highest for the overall observation period (142.3 and 130.7 cases per 100 thousand people accordingly).

Priority diseases among infants during their $1^{\text {st }}$ year of life included diseases of the blood and blood-forming organs and certain disorders involving the immune mechanism (139.2 per 1,000 infants) including anemia (130.4) and certain diseases occurring in a perinatal period (331.3).

We comparatively analyzed average longterm morbidity among population in Omsk and rural areas in Omsk region; the analysis revealed that morbidity among urban population was considerably higher than among rural one. Thus, for example, average long-term primary morbidity among children aged $0-14$ who lived in urban areas was 1.8 times higher than among their counterparts living in rural areas; as for specific diseases, morbidity with malignant neoplasms was 4.3 times higher; respiratory diseases, 1.9 times; digestive organs diseases, 2.8 times; skin and subcutaneous disuse diseases, 2.2 times.

Average long-term morbidity among infants in urban areas was also significantly higher than among infants in rural ones; overall morbidity was by 1.6 times higher; digestive organs diseases, 2.3 times; respiratory diseases, 1.9 times; specific diseases occurring in perinatal period, 1.8 times; congenital malformations, 3.5 times.

According to data obtained from research works there are certain health indicators that are associated with ambient air contamination; they are mortality caused by and morbidity with respiratory diseases, diseases of the di- gestive organs, circulatory system, malignant neoplasms, diseases of the blood and bloodforming organs, endocrine diseases, and neoplasms [2, 6, 9-12].

We calculated additional death cases and disease cases during 2017 caused by elevated average annual and average daily concentrations of particulate matter $\left(\mathrm{PM}_{2.5} ; \mathrm{PM}_{10}\right)$ registered at some monitoring posts ${ }^{8}$. Many Russian and foreign researchers state that particulate matter $\left(\mathrm{PM}_{2.5}, \mathrm{PM}_{10}\right)$ are an important indicator showing ambient air contamination and its influence on human health [4, 5, 8, 13-17].

A growth in average annual $\mathrm{PM}_{2.5}$ concentration equal to $0.0083 \mathrm{mg} / \mathrm{m}^{3}$ resulted in additional death cases among population in Omsk; there were 9 death cases caused by cardiovascular diseases added to the background level (453.9 deaths per 100 thousand people); 40 deaths caused by all reasons for people older than 30 added to the background number (957.3 per 100 thousand people).

A growth in average annual $\mathrm{PM}_{10}$ concentration equal to $0.0155 \mathrm{mg} / \mathrm{m}^{3}$ resulted in $7 \mathrm{ad}-$ ditional deaths caused by cardiovascular diseases among people living in Omsk; 47 additional chronic bronchitis cases among adults against the background level (248.0 disease cases per 100 thousand people).

According to tasks fixed within the Federal project in Omsk a Complex program was created; the Program included activities aimed at reducing contaminant emissions into ambient air for a period up to 2024 .

The Program contains environmental protection activities performed by enterprises that exert the most adverse influence on population health in Omsk and create intolerable risks. These are petrochemical enterprises and heatand-power engineering enterprises. Hazards were identified for all industrial objects that contaminated ambient air and aggregated standardized hazard quotients were determined for each enterprise. All the enterprises were ranked as per this quotient and it allowed us to spot out

\footnotetext{
${ }^{8}$ Calculations were accomplished according to the Methodical Guidelines MR 2.1.6.0156-19. Assessment of ambient air quality and health risk analysis aimed at making well-grounded managerial decisions in providing proper ambient air quality and sanitary-epidemiologic welfare of the population: methodical guidelines. Moscow, 2019 (in Russian).
} 
35 priority ones; 7 out of them took leading places as per their effects on population health leaving all the rest far behind (they were structural units belonging to HGC-11 heat generating company, Thermal power stations no. 4 and 5, Gazpromneft-Omskiy NPZ oil processing plant, Omskiy kauchuk JSC, Omsktechuglerod LLC, etc.).

According to the Complex program aggregated contaminants emissions should go down by $22.8 \%$ in 2024 against 2017 and it amounts to 56.212 thousand tons. And this reduction is envisaged mostly for stationary sources (33.7 thousand tons) and the remaining 22.56 thousand tons are from motor transport. Therefore, emissions from stationary sources are to fall from 163.7 thousand tons in 2017 to 130.0 thousand tons in 2024; emissions from mobile sources should decrease from 87.1 thousand tons to 64.5 thousand tons mostly due to new gas-filling compressor stations built in the city and use of gas as a fuel instead of petrol in vehicles.

We analyzed data on emissions from industrial enterprises (368 objects) as per 341 substances over 2017-2018 and classified then according to related hazards. As a result we obtained an updated list of priority contaminants including those that were not examined at monitoring posts.

As this updated list of priority contaminants was being created we primarily took into account indexes showing comparative carcinogenic and non-carcinogenic hazards, residential areas density, complaints from people about ambient air contamination and their territorial distribution; any violations of hygienic standards, dynamics of average annual concentrations, and contributions made into carcinogenic and non-carcinogenic risks. Besides, we paid serious attention to recommendations given by scientific experts on lists of priority contaminants for megacities $[3,18]$.

The list of priority contaminants obtained due to our research included the following chemicals: sulfur dioxide, nitrogen dioxide, hydrogen sulphide, carbon oxide, benzene, hydrocarbon black (soot), dimethylbenzene (xylene), hydroxybenzene (phenol), ammo- nia, methylbenzene (toluene), ethylbenzene, 3,4-benzpyrene, formaldehyde, chromium-VI, nickel oxide (recalculated as per nickel), and particulate matter $\mathrm{PM}_{10}, \mathrm{PM}_{2.5}$. We suggest systematic hygienic assessments and health risk assessments regarding these priority contaminants.

Examinations performed in Chita allowed obtaining a similar list of priority contaminants. But in Omsk maximum comparative carcinogenic and non-carcinogenic hazard indexes are by far lower than in Chita. Considerable volumes of contaminants emissions in both cities are due to heat-and-power generating enterprises and private households using coal as an energy source and climatic peculiarities of the regions [19].

Examinations accomplished in Krasnoyarsk indicate that autonomous sources also exert certain impacts on ambient air contamination that is above hygienic standards [20].

We determined priority contaminants in Omsk that should be subject to observation in order to detect violations of obligatory hygienic requirements when control and surveillance activities are performed without any interaction with economic entities; these contaminants are manganese, acrolein, methanethiol (methyl mercaptan), kerosene, 1,2-dichloroethane, acrylonitrile, carbon disulphide, hydrogen chloride, tetrachloromethane, trichloroethylene, copper, and cadmium.

Acrolein and 1.3-butadiene (divinyl) belong to priority contaminants but are not included into control programs. These substances are contained both in emissions from enterprises and motor transport. Thus, as per data provided by leading experts in risk assessment, 1,3-butadiene accounts for $26 \%$ of overall carcinogenic risk caused by emissions from motor transport [18].

Recent research accomplished in cities included as participants into «Clean air» Federal project allowed revealing that health risks are primarily created by the following contaminants: carbon, benzpyrene, benzene, sulfur dioxide, acrylonitrile, manganese, formaldehyde, nickel oxide, particulate matter including $\mathrm{PM}_{10}$ and $\mathrm{PM}_{2.5}$, and nitrogen dioxide [21]. 
The established list of priority contaminants should be used as a ground for an experiment on fixing quotas as well as for assessing results and efficiency (indulging economic one) of «Clean air» Federal project implementation basing on reduction in population health risks ${ }^{4}$.

The Complex program envisages that there should be reductions in priority contaminants emissions over 2019-2024, by $14.9 \%$ (24,220.8 tons) overall and carcinogens by $3.3 \%$ (24.9 tons).

Thus, for example, formaldehyde emissions should go down by $52.8 \%$ due to activities aimed at eliminating solid communal wastes sites everywhere in Omsk and reducing emissions from stationary sources that are mostly hydrocarbons-producing enterprises; chromium-VI emissions are to go down by $12.8 \%$ due to installing additional dust and gas traps at large chemical enterprises; benzpyrene and carbon black (soot) emissions should go down by $10.0 \%$ and $2.6 \%$ accordingly due to installing hybrid filters and modernizing technologic equipment at heat generating enterprises and tyres manufacturers.

At the same time, taking into account new goals on reducing emissions of priority contaminants by 2 times (that is, by $50 \%$ ) up to 2030 , it is necessary to set tasks on reducing emissions of risk-creating chemicals by not less than $20-25 \%$ up to 2024 .

Enterprises operating in Omsk that emitted the largest volumes of carcinogens (54 economic entities) were given certain suggestions on activities that should allow reducing emissions as per specific contaminants. 15 enterprises out of the list that made primary contributions into carcinogenic risks presented activity programs aimed at reducing emissions of nickel, chromium, benzene, carbon black (soot), benzpyrene, and formaldehyde; it allowed preparing additional alterations that should be made into the Complex program.
We, together with environmental protection authorities, assessed a system for monitoring over ambient air quality and estimated whether it was relevant to an actual sanitaryhygienic and ecologic situation in Omsk; the assessment was performed basing on spatial distribution of aggregated hazard quotient (S) over residential areas in Omsk taking into account potential effects produced by priority emission sources (industrial enterprises) on health of people living in the city ${ }^{9}$ (Figure). We created maps (layers) using a geoinformation system (ArcView GIS 3.2). Use of geographic information systems (GIS) allowed us to make our data more informative, and our analysis, more efficient [22].

In addition, we obtained preliminary data on aggregated calculated ground concentrations of contaminants in Omsk that took into account aggregated contaminants emissions from mobile sources (motor transport) and autonomous heat supplying sources ${ }^{10}$. Average daily (average annual) concentrations that were above hygienic standards were detected for benzpyrene; maximum single concentrations that were above hygienic standards were detected for 13 contaminants including those that were previously enlisted as priority contaminants, namely dimethyl benzene, hydroxybenzene, nitrogen dioxide, and sulfur dioxide; some substances were new such as dihydroperoxide, dihydrosulphide, and polyethylene polyamine. Reference concentrations that were above hygienic standards were registered at certain monitoring posts in the city center (No. 2 and 27) as per sulfur dioxide (up to $35 \%$ higher than the standard) and benzpyrene (up to $32 \%$ higher). Calculated average annual chromium concentrations were on average by 2 times higher than average chromium concentrations obtained via field observations and the situation was the same at all reference points that coincided with stationary posts for laboratory observations.

\footnotetext{
${ }^{9}$ The examination was performed according to the Methodical Guidelines MR 2.1.6.0157-19. Creation of programs for monitoring over ambient air quality and quantitative assessment of population exposure for fulfilling tasks within socialhygienic monitoring activities. Moscow, 2019 (in Russian).

${ }^{10}$ Calculations were performed by «NII ATMOSFERA» JSC in accordance with a state contract (in Russian).
} 


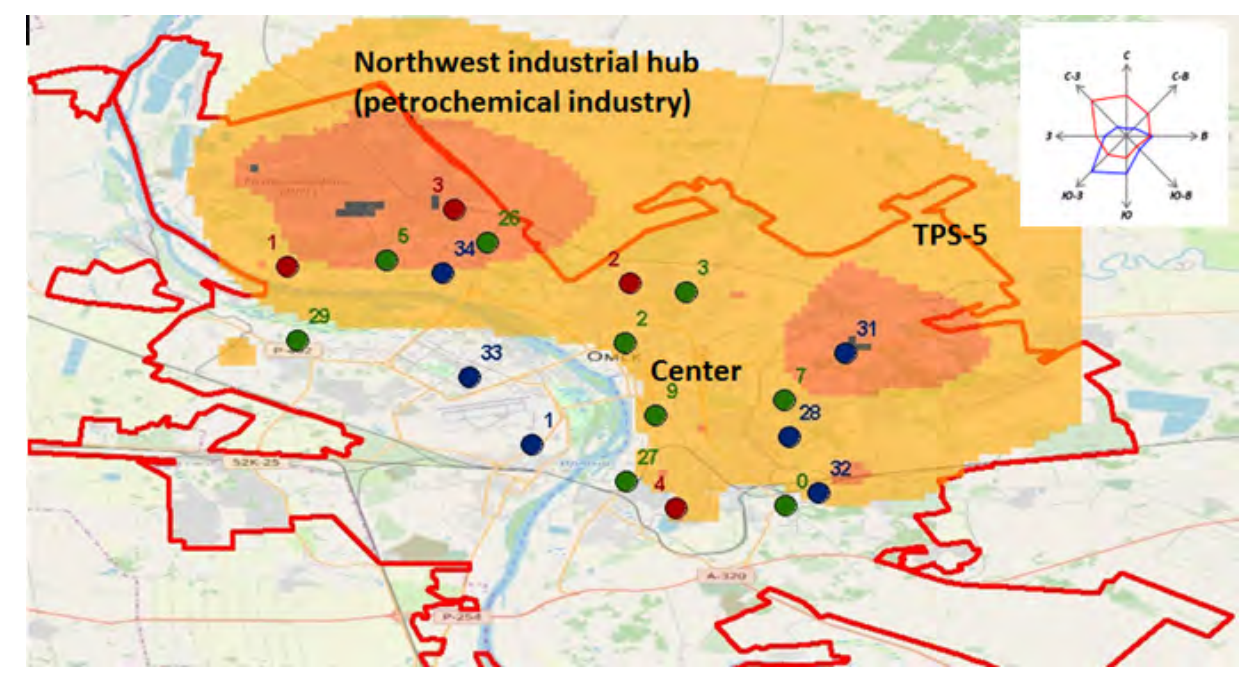

Figure. Spatial distribution of aggregated comparative hazard quotient (S) on Omsk city territory taking into account potential effects produced by industrial enterprises on residential areas in the city and predicted location of stationary posts for monitoring over ambient air quality for a period up to 2024

Symbols on the mal:

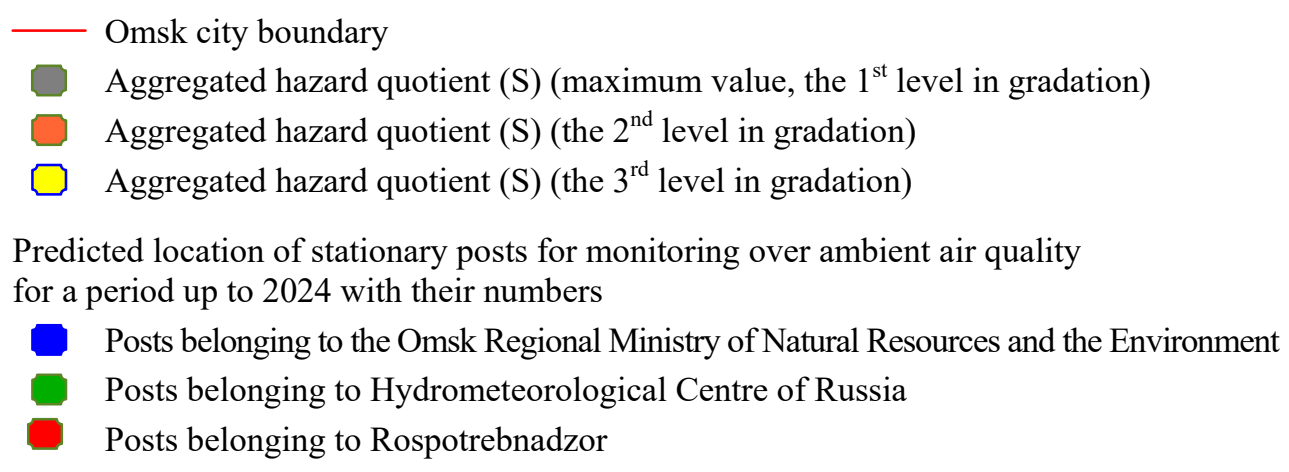

Therefore, we obtained certain arguments for preliminary substantiation of a program for monitoring over ambient air quality taking into account all monitoring systems belonging to different executive authorities responsible for environmental monitoring.

In 2019 (before optimization started) a laboratory network for monitoring over ambient air quality in Omsk included 10 stationary posts ( 6 posts belonged to Hydrometeorological Center of Russia and 4 posts, to the Omsk Regional Ministry of Natural Resources and the Environment), and a complete observation program was implemented at only 2 out of them. 25 chemicals were under surveillance at monitoring posts belonging to Hydrometeorological Center of Russia and 22 chemicals, at posts belonging to the Omsk Regional Ministry of Natural Resources and the Environment. Rospotrebnadzor Regional office in Omsk and Center for Hygiene and Epidemi- ology took air samples every month within a state program (laboratory examinations aimed at determining single concentrations) in zones influenced by the largest industrial objects. It was not sufficient bearing in mind proper health risk assessment as such samples could be used only for performing tentative hygienic assessments.

The existing monitoring network, despite minimal sufficient number of monitoring posts (10 for a city with million population) has certain drawbacks. They are as follows:

- posts are located in places that are not relevant bearing in mind intensity detected for spatial distribution of aggregated hazard quotients showing hazards caused by contaminants emitted from stationary sources taking wind rose into account: a situation in certain residential areas is not observed but these areas are influenced by petrochemical enterprises located in the northern part of the city; 
- monitoring at stationary posts does not cover residential areas in scopes it should: a distance between 2 posts was longer than $5 \mathrm{~km}$ and monitoring covered not more than $65 \%$ of total residential areas;

- a monitoring program implemented at monitoring posts did not correspond to hygienic tasks. On one hand, we should remember that average concentrations of certain metals such as cadmium, nickel, and chromium basically do not exceed maximum permissible ones; on the other hand, these substances have significant carcinogenic potential and when hazard are being identified thy usually take leading rank places in any lists of priority contaminants. We can't ignore this fact; therefore, a monitoring program should be altered in order to get as objective data on potential risks values as it is only possible. Thus, for example, 59 enterprises located in different parts of the city emit chromium into ambient air. Chromium occupies the $13^{\text {th }}$ rank place among all priority contaminants in the list obtained via hazard identification procedures but when it comes down to carcinogens it holds the $3^{\text {rd }}$ rank place. And preliminary aggregated calculations of ground chromium concentrations yielded higher annual average values than those obtained via field observations at all reference points. Sampling regarding chromium and other metals was performed only at 2 out of 10 monitoring posts within the existing ecological monitoring programs and examination programs were not comprehensive; single concentrations of those substances were averaged only once a month (for submitting data to Rospotrebnadzor authorities). Such priority contaminants as benzene, xylene, toluene, ethylbenzene, carbon black (soot), $\mathrm{PM}_{10}, \mathrm{PM}_{2.5}$, and metals either weren't examined in full scope or they were not monitored at all posts and it undoubtedly influenced health risk assessment making it less objective;

- there is no exchange of primary data obtained via laboratory examinations between Rospotrebnadzor Regional office in Omsk, the Omsk Regional Ministry of Natural Resources and the Environment, and Hydrometeorological Center of Russia.
Some researchers (V.N. Rakitskii, S.L. Avaliani, S.M. Novikov, T.A. Shashina) note that existing monitoring systems for control over quality of the environment have a specific drawback and it is their poor compatibility with requirements made by decision-makers and based on health risk analysis; it is due to existing monitoring systems not always being oriented at determining actual quantitative characteristics of population exposure and assessing related consequences for population health [23].

The performed examinations gave grounds for changes and the interdepartmental system for monitoring over ambient air quality has been substantially optimized; by 2024 it will include 19 stationary posts: 4 posts belonging to Rospotrebnadzor with 18 substances examined according to a complete observation program; 9 posts belonging to Hydrometeorological Center of Russia with 27 examined substances; 6 posts belonging to the Omsk Regional Ministry of Natural Resources and the Environment with 22 examined substances (according to the complete program at 5 posts, and according to a cut-down one at the remaining post). Location of most existing posts has been verified. We also substantiated placing additional posts in residential areas influenced by priority industrial objects, mostly in the northern-western part of the city (petrochemical production) and southern-eastern one (large coal-powered heat-generating enterprises) basing on spatial distribution of aggregated hazard quotient (S).

Taking into account preliminary data obtained via aggregated calculations on sulfur dioxide and benzpyrene concentrations exceeding their maximum daily average and reference levels, we justified placing additional monitoring posts No. 2 and 4 belonging to Rospotrebnadzor in zones influenced by main traffic highways and autonomous heating sources. When giving grounds for additional posts locations, we also took into account residential area density and absence of any posts belonging to either Hydrometeorological Center of Russia or the Omsk Regional Ministry of Natural Resources and the Environment located nearby. When this monitoring system is 
introduced, it will cover $98.3 \%$ residential areas in the city.

Therefore, implemented optimization of the laboratory network for monitoring over ambient air quality will allow obtaining more objective data on ambient air quality, revealing and assessing potential health risks including those caused by emissions from specific industrial enterprises, and implementing targeted and efficient activities aimed at health risk reduction.

Another task we pursued to solve in our research was assessing results obtained via the Complex program implementation and determining a list of indicators to be monitored.

If we want to fix reasonable target indicators, we should perform comprehensive analysis of available long-term monitoring data on environmental quality and these data should be supported by results obtained via modeling and/or health risk assessment. In accordance with recommendations given by leading experts on hygiene and sanitary a list of indicators that are subject to monitoring should reflect sufficiency and efficiency of activities implemented within «Clean air» federal project as per population health criteria [23, 24].

B.A. Revich, T.L. Khar'kova, and E.A. Kvasha suggest estimating population health in cities participating in "Clean air» federal project basing on such most precise and verified indicator as mortality. This indicator can be used when assessing impacts exerted by contaminated ambient air on health together with assessing prevalence of bronchial asthma and congenital malformations among children [25].

When we rely solely on aggregated emissions, it is impossible to identify the most hazardous substances and sources of their introduction into ambient air. Contaminants concentrations should be taken as indicators which are subject to monitoring within the Federal project; otherwise, it will be impossible to assess the project efficiency [1].

In our opinion, a list of indicators which are subject to monitoring (control) should include the following:

a) ambient air quality indicators (volumes of aggregated emissions as per each substance; average annual, average daily, and single maximum concentrations of priority substances);

b) indicators of individual lifelong carcinogenic risk and risks of non-carcinogenic effects produced on critical organs (systems) and as per specific substances; a share belonging to each substance in the structure of potential risks;

c) mortality and morbidity indicators associated with exposure to contaminated ambient air (taking into account regional peculiarities and specific contaminants) as well as a rate at which these indicators go down in comparison with average rates in the country;

d) number of additional unfavorable outcomes (deaths or disease cases) related to exposure to contaminants in concentrations that are above their levels fixed by hygienic standards;

e) economic indicators that estimate medical and demographic losses in money terms;

f) number of complaints and results obtained via social questionings performed among population and aimed at determining whether people are satisfied with ambient air quality.

Progress in achieving these target indicators should be estimated as per their target values calculated for each indicator which is subject to monitoring. Hygienic standards and permissible/minimal values of potential risks taken according to conventional classifications are to be used as target indicators.

We also suggest applying «acceptable risk level» concept for assessing risks levels. Maximum permissible value of acceptable health risk is established taking into account up-to-date available technical, technological, economic, and social instruments for providing safe and/or harmless environment. Acceptable health risk can be and should be fixed directly by a federal authority responsible for the state sanitary-epidemiologic surveillance or by the RF Government basing on reliable data submitted by such an authority [26, 27].

When it comes to mortality and morbidity indicators, we can be guided by average country levels; should there be epidemiologic models «ambient air contaminant - a nosology (nosologic group or category)», then we can obtain target indicators that reflect mortality and 
morbidity levels under average annual contaminants concentrations that are not higher than their reference levels. It is reasonable to apply target indicators that are not lower than values stipulated by «Healthcare» ${ }^{11}$ National project for some health indicators such as infant mortality, mortality caused by cardiovascular diseases and malignant neoplasms, and mortality among employable population.

Omsk experts performed scientific research on population health in the city and established population groups that were the most sensitive to effects produced by ambient air contamination; they were pregnant women and newborns; infant children younger than 1 year; children younger than 14 . Priority health indicators include overall and particular oncologic morbidity; indicators that show health of pregnant women and newborns; prevalence of respiratory and gastric diseases ${ }^{12}$.

Absence of additional death cases, disease cases, and admissions to hospitals caused by exposure to contaminants in concentrations higher than hygienic standards should be used as a target value for additional unfavorable outcomes.

In our opinion, target control indicators should include not only data collected for the whole city but also data on specific districts within it ranked as per an extent to which ambient air contamination influences exposed population's health.

The Table below contains an example of a report on target control indicators showing implementation of activities enlisted within the Complex plan $^{13}$ on emissions reduction and socially significant consequences as well as their assessment in dynamics taken over 2017-2019.

Year 2019 became the first one when environmental protection activities were implemented in accordance with the Complex program; preliminary results obtained in achieving target indicators were summed up.
In 2019 there were no average annual concentrations of any contaminants that were higher than hygienic standards; maximum single concentrations higher than hygienic standards were registered as per particulate matter (2 MPC), carbon oxide (1.7 MPC), nitrogen dioxide (1.4 MPC), nitrogen oxide (4.2 MPC), hydrogen sulphide (2.5 MPC), phenol (1.7 MPC), hydrogen chloride (8.8 MPC), ammonia (1.3 MPC), formaldehyde (6.3 MPC), ethylbenzene (6.5 MPC), and benzpyrene (3.6 MPC). Also in 2019 there was a growth in average annual concentrations of substances that make a considerable contribution into health risks such as benzene, formaldehyde, chromium, copper, and nickel. On the other hand, there was a decrease in annual average concentrations of such hazardous substances as benzpyrene, carbon black (soot), particulate matter, and nitrogen dioxide. A contribution made by those substances into carcinogenic and non-carcinogenic health risks went down substantially but it turned out not to be sufficient not only for risk reduction but also for preventing their growth.

Structure of carcinogenic risks determined as per substances changed with growing influence exerted by chromium and a decrease in contributions made by formaldehyde, benzene, and carbon black (soot), although aggregated specific weight of the three last contaminants still remained high $(44.3 \%)$.

Mortality caused by all reasons went down by $2.5 \%$ over the next two years (2018-2019) and was excluded from priority indicators with their values being higher than on average in the country and the Siberian Federal District. At the same time, mortality caused by respiratory diseases in Omsk grew by $4.7 \%$ against 2017. Infant mortality went down by $12.3 \%$ but the target indicator value was not yet achieved.

\footnotetext{
${ }^{11}$ Profile of «Healthcare» National project. Approved by the Presidium of the RF Presidential Council on strategic development and national projects (Meeting report No. 16 dated December 24, 2018). Garant. Available at: https://base.garant.ru/72185920/ (14.07.2020) (in Russian).

${ }^{12}$ V.A. Shirinskiy. Hygienic assessment of population health in a large administrative and industrial center during a socioeconomic crisis: the thesis of the dissertation ... for the Candidate of Medical Sciences degree. Saint Petersburg, 2003, 52 p. (in Russian).

${ }^{13}$ Data on «Clean air» Regional project implementation. Omsk Regional Government. Available at: https:// data.gov.ru/opendata/7703381225-transport (14.07.2020) (in Russian).
} 
Table

An example structure of target control indicators showing implementation of activities enlisted within the Complex plan on emissions reduction and their assessment in dynamics over 2017-2019, Omsk (a fragment of a report)

\begin{tabular}{|c|c|c|c|c|c|c|}
\hline \multirow{3}{*}{$\begin{array}{l}\text { A group of indicators/ } \\
\text { An indicator subject to } \\
\text { monitoring* }\end{array}$} & \multirow{3}{*}{\begin{tabular}{|c|} 
Average \\
long-term value \\
$(2009-2017)$
\end{tabular}} & \multicolumn{4}{|c|}{ Indicator taken as per years } & \multirow{3}{*}{$\begin{array}{c}\text { Assessment } \\
\text { whether a target } \\
\text { value achieved }\end{array}$} \\
\hline & & \multirow{2}{*}{$\begin{array}{c}2017 \\
\text { actual }\end{array}$} & \multirow{2}{*}{$\begin{array}{c}2018 \\
\text { actual }\end{array}$} & \multicolumn{2}{|c|}{2019} & \\
\hline & & & & actual & Target value & \\
\hline \multicolumn{7}{|c|}{ Volume f contaminants emissions into ambient air from stationary sources (tons per year) } \\
\hline Overall, including: & 181,070 & 163,700 & 186,500 & \begin{tabular}{|c|}
$161,390 * *$ \\
(went down by \\
2,310 tons, $1.4 \%$ )
\end{tabular} & $\begin{array}{c}159,800 \text { (should go } \\
\text { down by } 3,928 \text { tons } \\
\text { or } 2.4 \% \text { ) } \\
\end{array}$ & Not achieved \\
\hline formaldehyde & 12.5 & 10.52 & 10.45 & $\begin{array}{c}\text { Data will be avail- } \\
\text { able in the } 4^{\text {th }} \\
\text { quarter of } 2020\end{array}$ & $\begin{array}{l}\text { Should go down by } \\
8.8 \% \text { (9.6 tons) }\end{array}$ & \\
\hline \multicolumn{7}{|c|}{ MPC exceeding hygienic standards } \\
\hline $\begin{array}{l}\text { A share of samples with } \\
\text { contaminants in concen- } \\
\text { trations exceeding } \\
\text { maximum single MPC }\end{array}$ & $0.73 \%$ & $0.40 \%$ & $0.40 \%$ & $0.49 \%$ & $0.0 \%$ & $\begin{array}{l}\text { Not achieved; } \\
\text { growth }\end{array}$ \\
\hline \multicolumn{7}{|c|}{ Average annual contaminants concentrations obtained via environmental and social and hygienic monitoring } \\
\hline Benzene & 0.006 & 0.005 & 0.006 & 0.007 & $<0.03$ & $\begin{array}{l}\text { Achieved; } \\
\text { growth }\end{array}$ \\
\hline Benzpyrene & $8.3 \cdot 10^{-7}$ & $8.0 \cdot 10^{-7}$ & $8.8 \cdot 10^{-7}$ & $7.8 \cdot 10^{-7}$ & $<1.0 \cdot 10^{-6}$ & $\begin{array}{l}\text { Achieved; } \\
\text { growth }\end{array}$ \\
\hline Formaldehyde & 0.0087 & 0.007 & 0.0093 & 0.0095 & $<0.003$ & $\begin{array}{l}\text { Not achieved; } \\
\text { growth }\end{array}$ \\
\hline \multicolumn{7}{|c|}{ Individual lifelong carcinogenic risk } \\
\hline For overall population & $5.16 \cdot 10^{-4}$ & $2.45 \cdot 10^{-4}$ & $4.58 \cdot 10^{-4}$ & $4.69 \cdot 10^{-4}$ & $\begin{array}{c}<1.0 \cdot 10^{-4 \text { (acceptable }} \\
\text { level) }\end{array}$ & $\begin{array}{l}\text { Not achieved; } \\
\text { growth }\end{array}$ \\
\hline \multicolumn{7}{|c|}{ Hazard index for non-carcinogenic effects for substances with similar impacts } \\
\hline Respiratory organs & 11.5 & 9.82 & 10.69 & 11.39 & $\begin{array}{c}\leq 3.0 \\
\text { (acceptable level) }\end{array}$ & $\begin{array}{l}\text { Not achieved; } \\
\text { growth }\end{array}$ \\
\hline Immune system & 4.2 & 2.82 & 4.20 & 5.05 & $\begin{array}{c}\leq 3.0 \\
\text { (acceptable level) }\end{array}$ & $\begin{array}{l}\text { Not achieved; } \\
\text { growth }\end{array}$ \\
\hline \multicolumn{7}{|c|}{ Hazard index for non-carcinogenic effects for specific substances } \\
\hline Formaldehyde & 2.7 & 2.4 & 3.1 & 3.2 & $\begin{array}{c}\leq 1.0 \\
\text { (acceptable level) }\end{array}$ & $\begin{array}{l}\text { Not achieved; } \\
\text { growth }\end{array}$ \\
\hline Manganese & 1.4 & 1.4 & 1.2 & 1.0 & $\begin{array}{c}\leq 1.0 \\
\text { (acceptable level) }\end{array}$ & $\begin{array}{l}\text { Achieved; } \\
\text { decrease }\end{array}$ \\
\hline \multicolumn{7}{|c|}{ Population mortality in Omsk } \\
\hline $\begin{array}{l}\text { Mortality caused by } \\
\text { respiratory diseases per } \\
100 \text { thousand people }\end{array}$ & 49.0 & 38.0 & 36.0 & 39.8 & $\begin{array}{c}\text { Average country } \\
\text { level is } 49.1\end{array}$ & $\begin{array}{l}\text { Achieved; } \\
\text { growth }\end{array}$ \\
\hline Infant mortality & 5.1 & 5.7 & 5.58 & 5.0 & 4.5 & $\begin{array}{c}\text { Not achieved; } \\
\text { decrease }\end{array}$ \\
\hline \multicolumn{7}{|c|}{ Primary morbidity among population (per 100 thousand people from a relevant group) in Omsk } \\
\hline $\begin{array}{l}\text { Morbidity among children } \\
\text { younger than } 14 \text { with } \\
\text { asthma and status } \\
\text { asthmaticus }\end{array}$ & 143.46 & 134.4 & 98.2 & 205.3 & $\begin{array}{l}\text { Average country } \\
\text { level }{ }^{* *}\end{array}$ & $\begin{array}{l}\text { Drastic } \\
\text { growth }\end{array}$ \\
\hline \multicolumn{7}{|c|}{ Additional unfavorable outcomes for population caused by exposure to specific contaminants } \\
\hline $\begin{array}{c}\text { Number of death cases } \\
\text { caused by cardiovascular } \\
\text { diseases under exposure } \\
\text { to } \mathrm{PM}_{2.5}\end{array}$ & - & 9 & 0 & 0 & 0 & $\begin{array}{l}\text { Achieved; } \\
\text { decrease }\end{array}$ \\
\hline
\end{tabular}

Note:

* means that a list of indicators is given selectively to illustrate an example and is not complete;

** means data are preliminary, they will be adjusted in the $4^{\text {th }}$ quarter of 2020 . 
Primary morbidity went down as per most nosologies over 2018-2019; endocrine diseases and diseases of the skin and subcutaneous tissue were excluded from priority nosologies. Morbidity with diseases of the blood and blood-forming organs, anemia included, went down considerably among children and teenagers. Morbidity with gastric diseases, circulatory diseases, diseases of the nervous system, and congenital malformations was still included into priority nosologies lists. Besides, in 2019 morbidity with asthma and status asthmaticus tended to grow among children younger than 14 and adults aged 18 and older. Morbidity among infants also grew including morbidity with respiratory and gastric diseases and congenital malformations.

Conclusions. At initial stages in the Federal project implementation it is important to obtain the most objective data on population health risks caused by ambient air contamination including data on specific micro-territories; these data can be obtained due to creating a laboratory observation network for monitoring over ambient air quality that is relevant for hygienic tasks, and aggregated calculations of ground concentrations based on objective reports on emission sources.

The first year when environmental protection activities were implemented in accordance with the Complex program (2019) didn't bring about a «break-through» improvement in ambient air quality. Despite average annual concentrations of some contaminants truly went down, a lot of indicators didn't achieve their target values. Obviously, a socially significant effect - real improvement in population health - can be achieved only provided there is substantial and long-term decrease in ambient air contamination in residential areas. Some researchers who focus on the first results ob- tained via partially implemented activities within «Clean air» Federal project in participating cities mention that emissions reductions are not efficient enough when we consider their influence on population health [1].

Bearing in mind that new target figures envisage a 2-time reduction in priority contaminants emissions by 2030 (and it can truly lead to population health improvement), it is necessary to make changes into the Complex program in 2020 including new adjusting organizational and technical activities into it; these activities will allow providing a substantial reduction in emissions of risk-creating substances that should be not less than by $20-25 \%$ by 2024 against 2017 . It will be also necessary to enhance control over implementation of activities aimed at reducing emissions of the said substances.

We believe that providing objective and timely control over implementation of activities within the Federal project will require making a list of indicators which are subject to monitoring, collecting data in due time and controlling their quality, creating a system for target indicators assessment in order to provide operative reacting and making necessary corrections. It is especially important to determine relevant lists of socioeconomic indicators (health indicators) and ways to assess them properly; these indicators should be associated with ambient air quality and take into account regional peculiarities of ambient air contamination, climatic peculiarities in a specific region and socioeconomic conditions typical for it.

Funding. The research was not granted any sponsor support.

Conflict of interests. The authors declare there is no any conflict of interests.

\section{References}

1. Revich B.A. Natsional'nyi proekt «Chistyi vozdukh» v kontekste okhrany zdorov'ya naseleniya [«Clean air» federal project within the context of population health protection]. Ekologicheskii vestnik Rossii, 2019. Available at: http://ecovestnik.ru/index.php/2013-07-07-02-13-50/nashi-publikacii/3132natsionalnyjproekt-chistyj-vozdukh-v-kontekste-okhrany-zdorovya-naseleniya (07.07.2020) (in Russian).

2. Popova A.Yu. Strategic priorities of the Russian Federation in the field of ecology from the position of preservation of health of the nation. Zdorov'e naseleniya i sreda obitaniya, 2014, vol. 251, no. 2, pp. 4-7 (in Russian).

3. Air pollution and child health: prescribing clean air: summary. Geneva, World health organization Publ., 2018, 32 p. (in Russian) 
4. Abbey D.E., Hwang B.L., Burchette R.J., Vancuren T., Mills P.K. Estimated long-term ambient concentrations of PM10 and development of respiratory symptoms in a nonsmoking population. International Archives for Occupational and Environmental Health, 1995, vol. 50, no. 2, pp. 139-152. DOI: 10.1080/00039896.1995.9940891

5. Schindler C., Keidel D., Gerbase M.W., Zemp E., Bettschart R., Brändli O., Brutsche M.H., Burdet L. [et al.]. Improvements in PM10 exposure and reduced rates of respiratory symptoms in a cohort of Swiss adults (SAPALDIA). American Journal of Respiratory and Critical Care Medicine, 2009, vol. 179, no. 7, pp. 579-587. DOI: 10.1164/rccm.200803-388OC

6. Stepanova N.V., Yusupova N.Z., Khairullina L.R., Tselishcheva M.V. Environment-related morbidity of children population in Kazan. Voprosy shkol'noi $i$ universitetskoi meditsiny i zdorov'ya, 2019, no. 4, pp. 35-37 (in Russian).

7. Avaliani S.L., Novikov S.M., Shashina T.A., Dodina N.S., Kislitsin V.A., Skovronskaya S.A., Ivanova S.V., Matsyuk A.V. Printsipy upravleniya riskom zdorov'yu naseleniya na osnove analiza meropriyatii po snizheniyu promyshlennykh vybrosov [Principles of health risk management based on analysis of activities aimed at reducing industrial emissions]. Aktual'nye voprosy analiza riska pri obespechenii sanitarno-epidemiologicheskogo blagopoluchiya naseleniya i zashchity prav potrebitelei: sbornik po materialam VIII Vserossiiskoi nauchno-prakticheskoi konferentsii c mezhdunarodnym uchastiem. In: A.Yu. Popova, N.V. Zaitseva eds. Perm, 2018, pp. 14-19 (in Russian).

8. Tikhonova I.V., Koldibekova Yu.V., Zemlyanova M.A. Analiz prichinno-sledstvennykh svyazei izmeneniya nekotorykh biokhimicheskikh i funktsional'nykh pokazatelei u detei s povyshennym soderzhaniem $\mathrm{v}$ biosredakh khimicheskikh veshchestv, tropnykh $\mathrm{k}$ organam dykhaniya [Analysis of cause-and effect relations between changes in certain biochemical and functional parameters in children and increased concentrations of chemicals tropic to respiratory organs in biological media]. Profilakticheskaya meditsina-2019: sbornik nauchnykh trudov konferentsii Vserossiiskoi nauchno-prakticheskoi konferentsii c mezhdunarodnym uchastiem. Sankt-Peterburg, 2019, pp. 182-187 (in Russian).

9. Gigienicheskie aspekty narusheniya zdorov'ya detei pri vozdeistvii khimicheskikh faktorov sredy obitaniya [Hygienic aspects of health disorders in children under exposure to chemical environmental factors]. In: N.V. Zaitseva ed. Perm', Knizhnyi format Publ., 2011, 489 p. (in Russian).

10. Zaitseva N.V., Kiryanov D.A., Tsinker M.Yu., Kostarev V.G. Methodical approach to the investigation of reserves in the performance and management in the system of federal service for surveillance over consumer rights protection and human well-being (Rospotrebnadzor) as according to prevented health losses in the population of the Russian Federation. Gigiena i sanitariya, 2019, vol. 98, no. 2, pp. 125-134 (in Russian).

11. Boev V.M., Zelenina L.V., Kryazhev D.A., Tulina L.M., Neplokhov A.A. Analysis on exposure carcinogenic risk of environmental factors on health largest industrial cities and malignant tumors. Zdorov'e naseleniya i sreda obitaniya, 2016, vol. 279, no. 6, pp. 4-7 (in Russian).

12. Zaitseva N.V., Selyunina S.V., Tsinker M.Yu. Assessment of influence sanitary and hygienic and socio-economic factors of habitat on cancer incidence and onkosmertnosti indicators population of the Kirov region. Zdorov'e naseleniya i sreda obitaniya, 2014, vol. 255, no. 6, pp. 4-6 (in Russian).

13. Pope C.A., Burnett R.T., Thurston G.D., Thun M.J., Calle E.E., Krewski D., Godleski J.J. Cardiovascular mortality and long-term exposure to particulate air pollution: epidemiological evidence of general pathophysiological pathways of disease. Circulation, 2004, vol. 109, no. 1, pp. 71-77. DOI: 10.1161/01.CIR.0000108927.80044.7F

14. Lepeule J., Laden F., Dockery D., Schwartz J. Chronic exposure to fine particles and mortality: an extended follow-up of the Harvard Six City study from 1974 to 2009. Environmental Health Perspectives, 2012, vol. 120, no. 7, pp. 965-970. DOI: 10.1289/ehp.1104660

15. Lim S.S., Vos T., Flaxman A.D., Danaei G., Shibuya K., Adair-Rohani H., Amann M., Anderson H.R. [et al.]. A comparative risk assessment of burden of disease and injury attributable to 67 risk factors and risk factor clusters in 21 regions, 1990-2010: a systematic analysis for the Global Burden of Disease Study 2010. The Lancet, 2012, vol. 380, no. 9859, pp. 2224-2260. DOI: 10.1016/S0140-6736(12)61766-8

16. Novikov S.M., Shashina T.A., Khamidulina Kh.Kh., Skvortsova N.S., Unguryanu T.N., Ivanova S.V. Current problems in the system of state regulation of chemical safety. Gigiena i sanitariya, 2013, vol. 92, no. 4, pp. 19-24 (in Russian).

17. Zagorodnov S.Yu., May I.V., Kokoulina A.A. Fine-disperse particles $\left(\mathrm{PM}_{2.5}\right.$ and $\left.\mathrm{PM}_{10}\right)$ in atmospheric air of a large industrial region: issues related to monitoring and standardization of suspended particles in industrial emissions. Gigiena i sanitariya, 2019, vol. 98, no. 2, pp. 142-147 (in Russian). 
18. Revich B.A., Shaposhnikov D.A., Avaliani S.L., Lezina E.A., Semutnikova E.G. Changes in air quality in moscow in 2006-2012 and associated health risks. Problemy ekologicheskogo monitoringa i modelirovaniya ekosistem, 2015, vol. XXVI, no. 1, pp. 91-122 (in Russian).

19. May I.V., Kokoulina A.A., Balashov S.Yu. On the issue of optimization of atmospheric air quality monitoring for the implementation of the federal project «Clean air». Meditsina truda i promyshlennaya ekologiya, 2019, vol. 59, no. 11, pp. 931-936 (in Russian).

20. Goryaev D.V., Tikhonova I.V., Vasil'ev V.S. Ob organizatsii raboty po obespecheniyu kachestva atmosfernogo vozdukha $\mathrm{v}$ period provedeniya Vsemirnoi zimnei universiady v g. Krasnoyarske (2-12 marta 2019 g.) [On organizing activities aimed at providing ambient air quality during the Krasnoyarsk Winter Universiade 2019 (March 2-12, 2019)]. Aktual'nye voprosy obshchestvennogo zdorov'ya i zdravookhraneniya na urovne sub"ekta Rossiiskoi Federatsii: sbornik po materialam Vserossiiskoi nauchno-prakticheskoi konferentsii, posvyashchennoi 100-letiyu Irkutskogo gosudarstvennogo meditsinskogo universiteta. In: G.M. Gaidarov ed. Irkutsk, 2019, pp. 247-251 (in Russian).

21. Avaliani S.L., Shashina T.A., Dodina N.S., Kislitsin V.A., Mityagina A.V., Pogonina T.A. Opyt i perspektiva primeneniya analiza riska zdorov'yu pri realizatsii federal'nogo proekta «Chistyi vozdukh» dlya obespecheniya sanitarno-epidemiologicheskogo blagopoluchiya naseleniya [Experience and prospects in applying health risk analysis procedures in implementation of «Clean air» Federal project in order to provide sanitary-epidemiologic welfare of the population]. Analiz riska zdorov'yu - 2020 sovmestno s mezhdunarodnoi vstrechei po okruzhayushchei srede i zdorov'yu Rise-2020 i kruglym stolom po bezopasnosti pitaniya: sbornik po materialam X Vserossiiskoi nauchno-prakticheskoi konferentsii c mezhdunarodnym uchastiem. In: A.Yu. Popova, N.V. Zaitseva eds. Perm, 2020, pp. 231-239 (in Russian).

22. Karelin A.O., Lomtev A.Yu., Volkodaeva M.V., Eremin G.B. The improvement of approaches to the assessment of effects of the anthropogenic air pollution on the population in order to management the risk for health. Gigiena i sanitariya, 2019, vol. 98, no. 1, pp. 82-86 (in Russian).

23. Avaliani S.L., Shashina T.A., Dodina N.S., Kislitsin V.A., Sudakova E.V., Skovronskaya S.A., Ivanova S.V., Matsyuk A.V. Optimizatsiya sistemy monitoringa kachestva sredy obitaniya dlya tselei upravleniya riskom zdorov'yu naseleniya [Optimization of systems for monitoring over environmental quality in order to manage population health risk]. Aktual'nye voprosy analiza riska pri obespechenii sanitarnoepidemiologicheskogo blagopoluchiya naseleniya i zashchity prav potrebitelei: sbornik po materialam VIII Vserossiiskoi nauchno-prakticheskoi konferentsii c mezhdunarodnym uchastiem. In: A.Yu. Popova, N.V. Zaitseva eds. Perm, 2018, pp. 199-204 (in Russian).

24. Kachestvo atmosfernogo vozdukha $v$ megapolisakh i riski zdorov'yu naseleniya [Ambient air quality in megacities and population health risks]. Chelovek $v$ megapolise: opyt mezhdistsiplinarnogo issledovaniya. In: B.A. Revich, O.V. Kuznetsova eds. Moscow, LENAND Publ., 2018, 640 p. (in Russian).

25. Khar'kova T.L., Kvasha E.L., Revich B.A. Comparative assessment of mortality rate of the population in Russian and foreign megacities. Problemy prognozirovaniya, 2018, vol. 171, no. 6, pp. 150-159 (in Russian).

26. Popova A.Yu., Gurvich V.B., Kuz'min S.V., Mishina A.L., Yarushin S.V. Modern issues of the health risk assessment and management. Gigiena i sanitariya, 2017, vol. 96, no. 12, pp. 1125-1129 (in Russian).

27. Panchenko S.V., Novikov S.M., Shashina T.A., Arakelyan A.A. Ranging of radiation and chemical risks for health of population, problems and ways of their solutions. Ekologicheskaya, promyshlennaya i energeticheskaya bezopasnost' - 2018: sbornik statei po materialam mezhdunarodnoi nauchno-prakticheskoi konferentsii. In: L.I. Lukina, N.A. Bezhin, N.V. Lyamina eds. Sevastopol', 2018, pp. 930-933 (in Russian).

Kriga A.S., Nikitin S.V., Ovchinnikova E.L., Plotnikova O.V., Kolchin A.S., Cherkashina M.N., Vinokurova I.G., Dunaeva M.A. On implementation of «Clean air» federal project in Omsk. Health Risk Analysis, 2020, no. 4, pp. 32-46. DOI: 10.21668/health.risk/2020.4.04.eng

Received: 14.08 .2020

Accepted: 09.11.2020

Published: 30.12 .2020 